\title{
SPECIFIC PRESSOR ACTIVITY AND STABILITY OF SYNTHETIC ANGIOTENSINS
}

\author{
Takushi X. WATANABE, Hirofumi SOKABE, Ichiro HONDA*, \\ Shumpei SAKAKIBARA*, Taeko NAKAYAMA**, \\ and Terumi NAKAJIMA** \\ Department of Pharmacology, Jichi Medical School, Kawachi-gun, Tochigi-ken 329-04, \\ *Peptide Institute, Protein Research Foundation, Minoh 562, and \\ **Institutes of Pharmaceutical Sciences, Hiroshima University \\ School of Medicine, Hiroshima 734, Japan
}

Accepted September 27, 1976

\begin{abstract}
Specific pressor activity of $\mathrm{Asp}^{1}-\mathrm{Val}^{5}$-angiotensins I and II was determined 1) by a 4-point assay in rats against various synthetic angiotensins. Specific pressor activity of various angiotensins was also obtained from the dose-blood pressure-response (DR) curve, using a single angiotensin sample per rat. Comparison of two values showed that two angiotensins interacted in the 4-point assay, yielding a potentiation factor of $0.465-1.373$. Therefore, specific pressor activity from DR curve is more reliable, because two angiotensins are not able to interact. Potency ratio on a molar

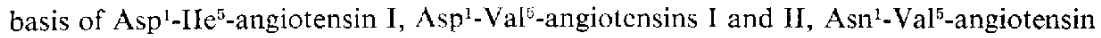
II (Ciba Lot-094691), and $\mathrm{Asp}^{1}-\mathrm{Val}^{5}{ }^{5}-\mathrm{Ser}^{3}$-angiotensin I against $\mathrm{Asp}^{1}-\mathrm{II}^{\overline{5}}$-angiotensin Il were $0.76,0.91,2.02,0.50$, and 1.39, respectively. Asp ${ }^{1}-V_{a l}^{5}$-angiotensin II had twice the pressor activity of Asp ${ }^{1}-I_{e^{5}}$-angiotensin II. Lyophylized Asp IIIe $^{5}$-angiotensins I and II kept desiccated at $-20^{\circ} \mathrm{C}$, were stable for 27 months. Solutions of 100,10 , and $0.8 \% \mathrm{~g} / \mathrm{ml}$ were stable for 12,8 , and 6 months at $-20^{\circ} \mathrm{C}$, respectively.
\end{abstract}

In the previous study (1), we re-examined the specific pressor activity of Asp-IIesangiotensins $I$ and $I I$ in the rat by a 4-point assay. The pressor activity of Asp'-IIe-angiotensin II was greater than that of $\mathrm{Asn}^{1}-\mathrm{Val}^{5}$-angiotensin II. The potency ratio of $\mathrm{Asp}^{1}$-Ilesangiotensin I to II was 0.63 on a molar basis. In the present study, we extended the deter-

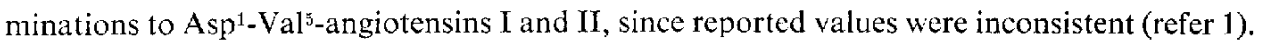
Using this assay system we also determined stability of $\mathrm{Asp}^{1}$-Ile $\mathrm{e}^{5}$-angiotensins I and II.

Specific pressor activity of $\mathrm{Asp}^{1}-\mathrm{Val}^{5}$-angiotensins I and II was influenced to various degrees by other angiotensins used as the standard in the 4-point assay. This was also true for Asp'-Vals-Ser'-angiotensin I (2). The value from a direct comparison was not in accord with those obtained indirectly using a third angiotensin as the standard. We, therefore, calculated specific pressor activity from the dose-blood pressure-response (DR) curve, obtained by injecting a single angiotensin sample per assay rat. This activity was compared to that obtained by the 4-point assay. We found that the value from DR curves was more reliable.

The purpose of this paper is to report (i) specific pressor activity of Asp ${ }^{1}$-Val ${ }^{5}$-angiotensins I and II determined by a 4-point assay, (ii) specific pressor activity of synthetic angiotensins obtained from DR curves, (iii) comparison of the above two values, and finally (iv) stability of Asp ${ }^{1}-\mathrm{Il} \mathrm{e}^{5}$-angiotensins $\mathbf{I}$ and II. 


\section{MATERIALS AND METHODS}

We synthesized Asp ${ }^{1-V a l}{ }^{5}$-angiotensins I and II by the classical procedures. Purification and determination of weights were as reported previously (1). Asp'-Ile ${ }^{5}$-angiotensins I and II were also treated by the same procedures. Samples in ampoules of $\mathrm{Asn}^{1}{ }^{1-V a l^{5}}$-angiotensin II (Ciba Lot-094691) were used without purifying or weighing. They showed ca. 0.80 of pressor activity to the purified sample. Asp ${ }^{1-V_{a l}}{ }^{5}-\mathrm{Ser}^{9}$-angiotensin I (fowl angiotensin (I)) was sysnthesized by solid-phase procedure and purified (2).

Preparation of rats, assay procedures, and statistical analyses were the same as in the previous report (1). Female rats of the Donryu/HOS strain, weighing $200 \pm 20$ g, were used. Angiotensins were dissolved in $0.3 \mathrm{ml}$ of $9 \mathrm{mg} / \mathrm{ml} \mathrm{NaCl}$ containing $10 \mathrm{nl} / \mathrm{ml}$ Tween 20 , and injected intravenously. A 4-point assay was performed on combinations of angiotensins in 6 rats each. Low and high doses were 0.5 and $5.0 \mathrm{mg}$ for Asp'-Val ${ }^{5}$-angiotensin II, 0.1 and $10 \mathrm{ng}$ for Asp ${ }^{1}-\mathrm{Il}^{5}$-angiotensin II and $\mathrm{Asp}^{1}-\mathrm{Val}^{3}-\mathrm{Ser}^{9}$-angiotensin I, and 0.2 and $20 \mathrm{ng}$ for the rest of angiotensins. Tachyphylaxis did not occur with these low doses. In fact, pressor responses usually became larger during the course of repeated injections in 20 times. PRw and PRm are designated to potency ratio on a weight and a molar basis, respectively. The 4-point assay was used throughout the determination of stability of angiotensins.

DR curves were obtained by injecting 0.2 to $40 \mathrm{ng}$ of angiotensins in each 6 rats. Tachyphylaxis should be slight when injecting angiotensins in the increasing doses up to $40 \mathrm{ng}$. Specific pressor activity was also calculated from DR curves. A dose of angiotensin to elicit blood pressure rise by $30 \mathrm{mmHg}$ was determined from each DR curve. PRw and PRm were obtained as the ratio of these doses. The $95 \%$ confidence interval was calculated by Filler's equation (3).

\section{RESULTS}

Specific pressor activity of 5-valine-angiotensins $I$ and II by 4-point assay

Results are shown in Table 1. PRm of Asp'-Val'-angiotensin I against Asp'-Val' angiotensin II by the direct comparison was 0.615 , while the values calculated from PRm against the third angiotensins were $0.431,0.543$, and 0.640 , respectively. The first two figures were less than the $95 \%$ confidence limit of PRm obtained by the direct comparison, indicating that two angiotensins may interact in 4-point assay. The same discrepancy was observed during 4-point assay of $\mathrm{Asp}^{1-}-\mathrm{Val}^{5}-\mathrm{Ser}^{9}$-angiotensin I (2).

Dose-blood pressure-response curves of synthetic angiotensins $I$ and II

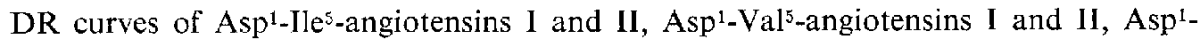
$\mathrm{Val}^{5}{ }^{5}-\mathrm{Ser}^{9}$-angiotensin I (fowl angiotensin (I)), and $\mathrm{Asn}^{1}$-Val'5-angiotensin II were obtained (Fig. 1). Relative potencies of these angiotensins were determined from the DR curves (Table 2).

Comparison of specific pressor activitics by 4-point assay and from $D R$ curves

Specific pressor activities of two angiotensins, obtained by direct comparison in the 4-point assay and calculated from DR curves were not always in accord. DR curves made 
TABLE 1 Specific pressor activity of $\mathrm{Va}^{5}$-angiotensins $\mathrm{I}$ and II in the rat by 4-point assay

\begin{tabular}{|c|c|c|c|}
\hline$T$ & $S$ & PRw & PRm \\
\hline \multirow[t]{4}{*}{ Asp'-Vals-Ang I } & $A s p^{1}-11 e^{5}-A n g I$ & $\begin{array}{c}0.942 \\
(0.843-1.053)\end{array}$ & $\begin{array}{c}0.932 \\
(0.834-1.042)\end{array}$ \\
\hline & Asp ${ }^{1}-\left[1 e^{5}-A n g I I\right.$ & $\begin{array}{c}0.505 \\
(0.479-0.532)\end{array}$ & $\begin{array}{c}0.619 \\
(0.588-0.652)\end{array}$ \\
\hline & Asp $-\mathrm{Val}^{5}$-Ang II & $\begin{array}{c}0.495 \\
(0.453-0.540)\end{array}$ & $\begin{array}{c}0.615 \\
(0.563-0.671)\end{array}$ \\
\hline & $\begin{array}{l}\text { Asn'-Val }{ }^{5}-\text { Ang II } \\
\text { (Ciba Lot-094691) }\end{array}$ & $\begin{array}{c}0.974 \\
(0.863-1.098)\end{array}$ & $(1.074-1.366)$ \\
\hline \multirow[t]{3}{*}{ Asp ${ }^{1}-\mathrm{Val}^{5}$-Ang II } & $\operatorname{Asp}^{1}-I \mathrm{I}^{5}$-Ang I & $\begin{array}{c}2.716 \\
(2.554-2.889)\end{array}$ & $\begin{array}{c}2.163 \\
(2.034-2.300)\end{array}$ \\
\hline & Asp $^{1}-I^{-5} e^{5}$ Ang II & $\begin{array}{c}1.157 \\
(1.061-1.261)\end{array}$ & $\begin{array}{c}1,141 \\
(1.047-1.245)\end{array}$ \\
\hline & $\begin{array}{l}\text { Asn }{ }^{1}-\mathrm{Val}^{5}-\mathrm{Ang} \text { II } \\
\text { (Ciba Lot-094691) }\end{array}$ & $\begin{array}{c}1.892 \\
(1.678-2.133)\end{array}$ & $\begin{array}{c}1.893 \\
(1.679-2.135)\end{array}$ \\
\hline
\end{tabular}

T: test material, $\mathbf{S}$ : standard material, PRw : potency ratio on a wt. basis, PRm: potency ratio on a molar basis. The $95 \%$ confidence interval is in parentheses.
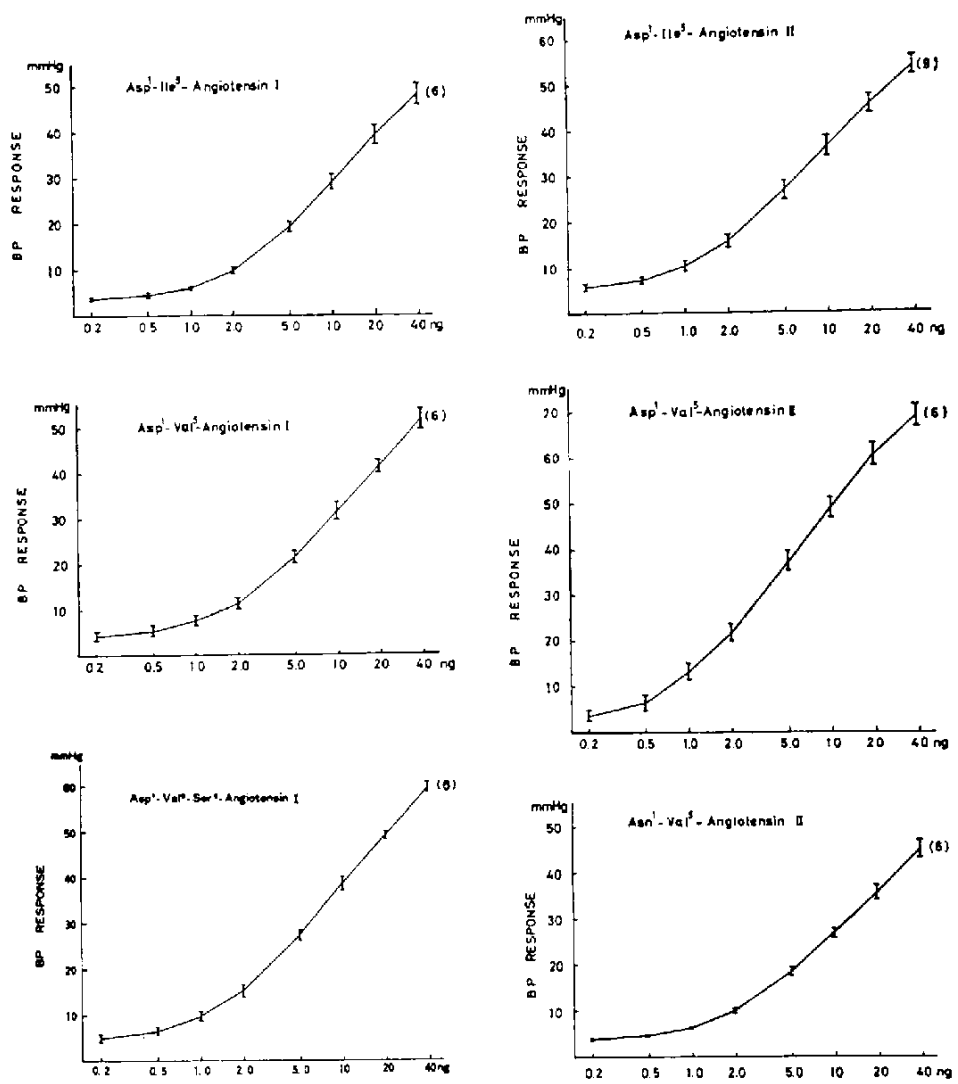

FIG. 1 Dosc-blood pressure response curves of synthetic angiotensins. Vertical bar represents SEM. No. of assays in parentheses. 
TABLE 2 Specific pressor activity of synthetic angiotensins in the rat from DR curves

\begin{tabular}{|c|c|c|c|c|}
\hline Angiotensin & & $\mathrm{PR} w$ & & PRm \\
\hline Asp $p^{1}-I I e^{5}$-Ang I & 0.616 & $(0.536-0.696)$ & 0.763 & $(0.664-0.863)$ \\
\hline Asp $p^{1}-I I e^{5}-$ Ang II & 1.00 & $(0.856-1.144)$ & 1.00 & $(0.856-1.144)$ \\
\hline Asp $^{1}-V_{a}{ }^{5}-$ Ang I & 0.738 & $(0.635-0.841)$ & 0.905 & $(0.778-1.031)$ \\
\hline Asp $p^{1}-V a l^{5}-$ Ang II & 2.047 & $(1.475-2.619)$ & 2.020 & $(1.455-2.584)$ \\
\hline $\begin{array}{l}\text { Asn'-Vat }{ }^{5} \text {-Ang II } \\
\text { (Ciba Lot-09469l) }\end{array}$ & 0.504 & $(0.443-0.566)$ & 0.497 & $(0.437-0.558)$ \\
\hline Asp $-Y a l^{5}-$ Ser $^{9}$-Ang I & 1.145 & $(0.941-1.349)$ & 1.389 & $(1.141-1.636)$ \\
\hline
\end{tabular}

PRw: potency ratio on a wt. basis, PRm: potency ratio on a molar basis. The $95 \%$ confidence interval is in parentheses.

TABLE 3 Comparison of specific pressor activities by 4-point assay and from DR curves

\begin{tabular}{|c|c|c|c|c|}
\hline $\mathrm{T}$ & $\mathbf{S}$ & $\operatorname{PRm}(4 \mathrm{PA})$ & $\operatorname{PRm}(\mathrm{DRC})$ & 4PA/DRC \\
\hline \multirow[t]{2}{*}{ Asp $p^{1}-I l e^{5}-A n g I$} & Asp'-Ile -Ang II & 0.632 & 0.763 & 0.828 \\
\hline & $\begin{array}{l}\text { Asn'-Val5-Ang II } \\
\text { (Ciba Lot-094691*) }\end{array}$ & 1.125 & 1.536 & 0.732 \\
\hline Asp ${ }^{1}-I l e^{5}-A n g$ II & $\begin{array}{l}\text { Asn'-Va! }{ }^{5} \text {-Ang II } \\
\text { (Ciba Lol-094691*) }\end{array}$ & 1.636 & 2.012 & 0.813 \\
\hline \multirow[t]{4}{*}{ Asp $-V a l^{5}$-Ang I } & Asp'-Ile $-A n g I$ & 0.932 & 1.185 & 0.786 \\
\hline & Asp ${ }^{1}-I l e^{5}-$ Ang II & 0.619 & 0.905 & 0.684 \\
\hline & Asp'-Val'5-Ang II & 0.615 & 0.448 & 1.373 \\
\hline & $\begin{array}{l}\text { Asn'-Val }{ }^{5}-\text { Ang II } \\
\text { (Ciba Lot-094691) }\end{array}$ & 1.211 & 1.820 & 0.665 \\
\hline \multirow[t]{3}{*}{ Asp $p^{1}-\mathrm{Val}^{5}-$ Ang II } & Asp'-Ile ${ }^{5}$-Ang I & 2.163 & 2.647 & 0.817 \\
\hline & Asp'-Ile ${ }^{5}-\wedge n g$ II & 1.141 & 2.020 & 0.565 \\
\hline & $\begin{array}{l}\text { Asn'-Val'-Ang II } \\
\text { (Ciba Lot-094691) }\end{array}$ & 1.893 & 4.067 & 0.465 \\
\hline \multirow[t]{4}{*}{ Asp $1-V a l^{5}-S^{2} r^{9}$-Ang $I$} & $A s p^{1}-I l e^{5}-A n g I$ & 1.570 & 1.818 & 0.864 \\
\hline & Asp $^{1}-I_{1}^{5}$-Ang II & 1.141 & 1.389 & 0.821 \\
\hline & $\mathrm{Asp}^{1}-\mathrm{Yal}^{5}$-Ang I & 1.808 & 1.534 & 1.179 \\
\hline & Asp'-Yal ${ }^{5}$-Ang II & 0.851 & 0.687 & 1.239 \\
\hline
\end{tabular}

T: test material, $\mathrm{S}$ : standard matcrial, PRm (4PA): potency ratio on a molar basis by 4-point assay, PRm (DRC): PRm from DR curves, 4PA/DRC: ratio of PRm by 4-point assay and from DR curves. Part of PRm (4PA) values were reported previously $(1,2)$. *Calculated from the result of Ciba Lot-171671.

from the results in the 4-point assay shifted to the left in various degrees from those obtained above, indicating that potentiation occurred during the assay. Pressor responses usually became larger during the course of the 20 repeated injections of angiotensin. We calculated the ratio of PRm by 4-point assay to that from DR curve (4PA/DRC) (Table 3). The values ranged from $0.465-1.373$, indicating that two angiotensins interacted to various degrees.

Stability of 5-isoleucine-angiotensins $I$ and $I I$

Angiotensins, $0.5 \mathrm{mg}$, were lyophylized in vials, and dissolved at concentrations of 
Table 4 Stability during the stock as lyophilized material at $-20^{\circ} \mathrm{C}$

\begin{tabular}{ccccc}
\hline $\begin{array}{c}\text { Duration } \\
\text { (months) }\end{array}$ & $\begin{array}{c}\text { S } \\
\text { (vial no.) }\end{array}$ & $\begin{array}{c}\mathrm{T} \\
\text { (vial no.) }\end{array}$ & $\begin{array}{c}\text { Asp'-1le }{ }^{5} \text {-Ang I } \\
\text { PRw }\end{array}$ & $\begin{array}{c}\text { Asp'-1le } \\
\text { PRw }\end{array}$ \\
\hline 0 & 1 & 1 & $0.840(0.683-1.030)$ & $1.414(1.232-1.627)$ \\
& 1 & 2 & $0.929(0.819-1.053)$ & $1.470(1.267-1.712)$ \\
27 & 1 & 1 & $0.929(0.773-1.116)$ & $1.692(1.487-1.922)$ \\
& 2 & 1 & $1.032(0.808-1.318)$ & $1.638(1.386-1.931)$ \\
& 1 & 2 & $1.065(0.793-1.431)$ & $1.828(1.598-2.089)$ \\
& 2 & 2 & $0.971(0.842-1.119)$ & $1.566(1.440-1.701)$ \\
\hline
\end{tabular}

S: Standard material. Asn'-Val'-Ang II (Ciba Lot 094691) is used. T: Test material. PRw: potency ratio on a wt. basis. The $95 \%$ confidence interval is in parentheses.

TABIF 5 Stability during stock as a solution at $-20^{\circ} \mathrm{C}$

\begin{tabular}{cccc}
\hline $\begin{array}{c}\text { Concentration } \\
(\mu \mathrm{g} / \mathrm{ml})\end{array}$ & $\begin{array}{c}\text { Duration } \\
(\mathrm{m})\end{array}$ & $\begin{array}{c}\text { Asp }^{1}-\text { Ile }^{5} \text {-Ang I } \\
\text { PRw }\end{array}$ & $\begin{array}{c}\text { Asp'-lle } \\
\text { PRw Ang II }\end{array}$ \\
100 & 4 & $0.988(0.907-1.097)$ & $1.049(0.874-1.260)$ \\
& 8 & $1.016(0.873-1.183)$ & $0.963(0.817-1.135)$ \\
& 12 & $0.920(0.750-1.128)$ & $1.040(0.853-1.269)$ \\
\hline
\end{tabular}

The same angiotensin solution newly dissolved from a vial was used as the standard. PRw: potency ratio on a wt. basis. The $95 \%$ confidence interval is in parenthescs.
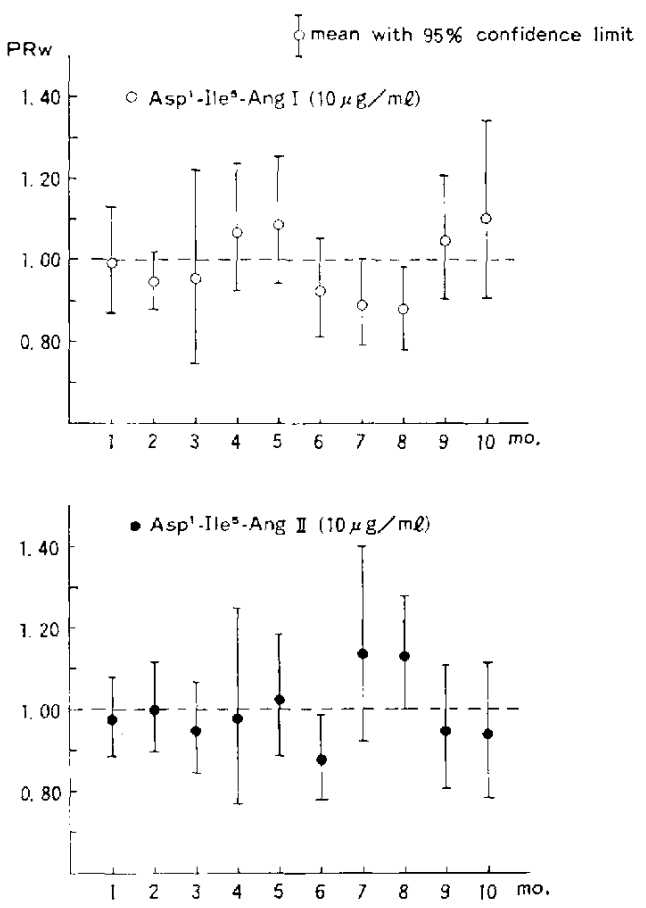

DURATION OF STOCK $(-20 \mathrm{C})$

Fig. 2 Stability of angiotensin solutions $(10 / \mathrm{g} / \mathrm{ml}) \mathrm{kepl}$ frozen at $-20^{\circ} \mathrm{C}$. The same angiotensin solution ncwly dissolved from the stock solution of higher concentration was used as the standard. 

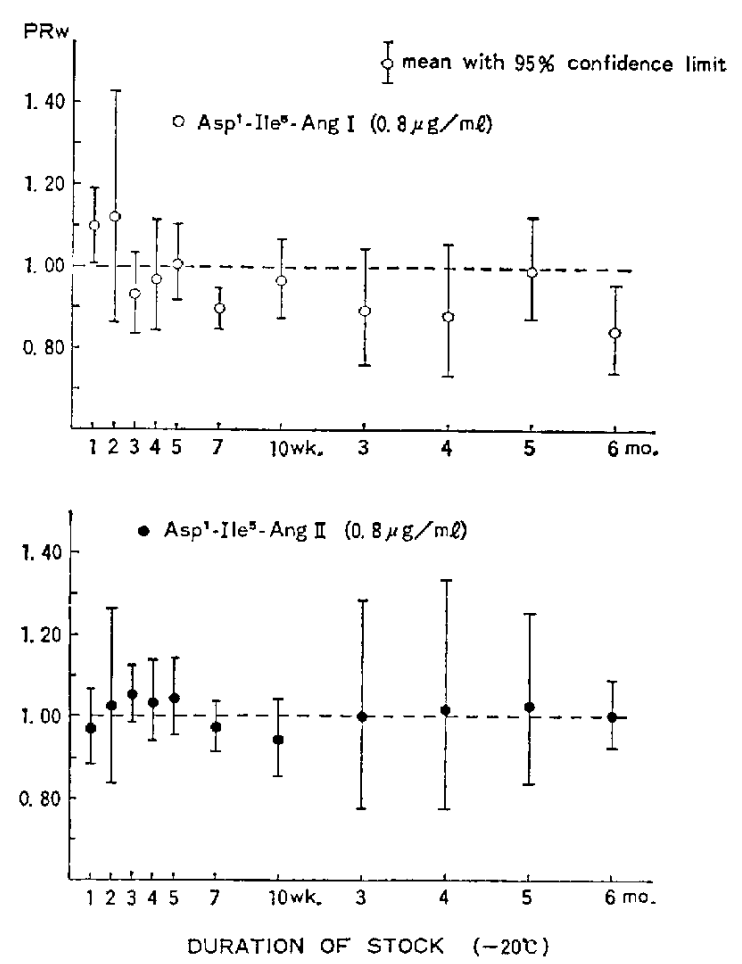

Fig. 3 Stability of angiotensin solutions $(0.8 \mu \mathrm{g} / \mathrm{ml})$ kept frozen at $-20^{\circ} \mathrm{C}$. The standard was the same as in Fig. 2.

100,10 , and $0.8 \mu \mathrm{g} / \mathrm{ml}$ as stock solutions, then diluted further for assay. Angiotensins I or II was recovered equally from 4 different vials, indicating that variation of the amount of angiotensins among vials or of yields by dissolution from vials did not exceed the errors in bioassay. Four samples of $100 \mu \mathrm{g} / \mathrm{ml}$ solution were made from a vial, diluted further, and bioassayed. The variations in this step also did not exceed those in the bioassay.

Angiotensins I and II in vials were kept desiccated at $-20^{\circ} \mathrm{C}$ for 27 months. Each 2 vials were compared to $\mathrm{Asn}^{1}-\mathrm{Val}^{5}$-angiotensin II kept in the same way. PRw of angiotensins $\mathbf{I}$ and II were increased, indicating that decay in activity of Asn ${ }^{1}$-Val ${ }^{5}$-angiotensin II was greater than those of $\mathrm{Asp}^{1}-\mathrm{Ile}^{5}$-angiotensins I and II (Table 4). Net rises in blood pressure, and comparison of the activity against newly synthesized lots indicated that angiotensins I and II did not lose activity for 27 months under this condition.

Stock solutions of angiotensins I and II were kept at $-20^{\circ} \mathrm{C}$. A solution of $100 \mu \mathrm{g} / \mathrm{ml}$ concentration did not lose the activity for 12 months (Table 5). A solution of $10 \mu \mathrm{g} / \mathrm{ml}$ of angiotensin $I$ tended to increase in activity and that of angiotensin II to decrease after 9 and 10 months (Fig. 2). Although the differences did not exceed the errors in bioassay, the stock solutions of $10 \mu \mathrm{g} / \mathrm{ml}$ were stable for at least 8 months. A solution of $0.8 \mu / \mathrm{g} / \mathrm{ml}$ was stable for 6 months at $-20^{\circ} \mathrm{C}$ (Fig. 3). Solutions $(0.8 \mu / \mathrm{g} / \mathrm{ml})$ frozen and thawed 4 times did not lose the activity. 


\section{DISCUSSION}

Although the activities of two angiotensins can be compared in an assay preparation by the 4-point assay, the potency ratio deviates if two angiotensins interact. This interaction occurred yielding potentiation factors (4PA/DRC ratio in Table 3 ) of $0.465-1.373$. If the ratio is larger than 1.0 , it means that either the test material $(\mathrm{T})$ is potentiated by standard material (S), or $\mathrm{S}$ is inhibited by $\mathrm{T}$. If the ratio is smaller than 1.0 , either $\mathrm{T}$ is inhibited by $\mathrm{S}$ or $\mathrm{S}$ is potentiated by $\mathrm{T}$.

The specific activity by 4-point assay is correct only for the combination of angiotensins applied to the assay preparation alternatively. The value from a direct comparison was not in accord with those obtained indirectly using a third angiotensin as the standard. Therefore, we concluded that specific activity from DR curves (Table 2) should be used for the general discussion.

The values are expressed as the activity of $\mathrm{Asp}^{1}-\mathrm{Ilc}^{5}$-angiotensin II equal to 1.00, because it is the common active form of mammalian angiotensin (4). Asn ${ }^{1}$-Val's-angiotensin II should not be used as the standard because of its relatively unstable shelf life. It has

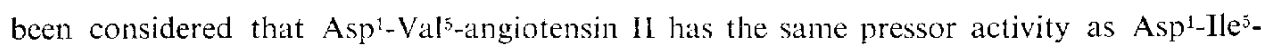
angiotensin II $(5,6$, refer also Table 1 in 1$)$, but such was proved otherwise in our present study. Higher activity is probably die to relative resistance to angiotensinases (7).

Potency ratio of Asp $\mathrm{As}^{1}-1 \mathrm{e}^{5}$-angiotensin I to II was 0.763 on a molar basis, while that of Asp'-Val ${ }^{1}$-angiotensin I to II was 0.448 . This may indicate that conversion of Asp ${ }^{1-V a l^{5}-}$

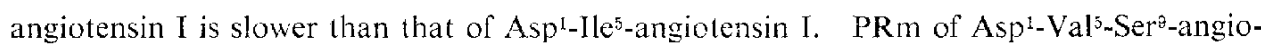

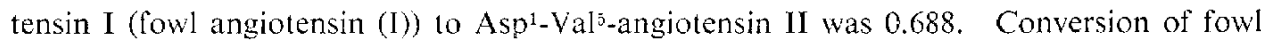
angiotensin (I) may be faster than so-called bovine angiotensin $I$ (Asp ${ }^{1}-\mathrm{Val}^{5}$-angiotensin I) in the rat.

The results on stability of $\mathrm{Asp}^{1}-\mathrm{Il} \mathrm{e}^{5}$-angiotensins I and II are: (i) variation in the amounts of lyophylized materials in vials was negligible, (ii) variation in yield from vials when dissolving was negligible, (iii) angiotensin in the vial kept desiccated at $-20^{\circ} \mathrm{C}$ was stable for 27 months, (iv) $100 / 2 \mathrm{~g} / \mathrm{ml}$ solutions were stable for 12 months at $-20^{\circ} \mathrm{C}$, and 10 and 0.8 $/ \mathrm{g} / \mathrm{ml}$ solutions were stable for 8 and 6 months, respectively, and (v) $0.8 \mu \mathrm{gg} / \mathrm{ml}$ solutions were stable even when freezing and thawing were repeated 4 times.

Acknowledgements: We are indepted to Drs. M.C. Khosla and F.M. Bumpus for synthesis of Asp'-Val'-Ser'-angiotensin I. We thank Mrs. M. Sokabe, and Ms. Y. Kurihara for technical assistance, and Misses $H$. Suzuki and $K$. Iso for secretarial assistance. We also thank Dr. A. Sakuma for advice on the statistical analyses. Preliminary reports of this study were given at the $53 \mathrm{rd}$ and 54 th Kanto Regional Meetings of the Japancse Pharmacological Society $(8,9)$. This investigation was supported by a Granl-in-Aid for Scientific Research (Tokutei (1)-911811, \& -011511 in 1974-5) from the Ministry of Education, Japan.

\section{REFERENCFS}

1) Nakalima, T., Sakamibara, S., Sakuma, A. and Sokabe, H.: Japan. J. Phamacol. 23, 591 (1973) 
2) Khosla, M.C., Bumpus, F.M., Hayashi, Y., Nakajima, T. Watanabe, T.X. a.d Sokabe, H.: J. med. Chem. (in press)

3) Sakuma, A.: Bioassay, p. 145, University of Tokyo Press, Tokyo (1970) (in Japanese)

4) Sokabe, H. and OGawa, M.: Int. Rev. Cytol. 37, 271 (1974)

5) Gross, F. and Turrian, H.: Polypeptides Which Affect Smooth Muscles and Blood Vessels, Edited by Schachter, M., p. 137, Pergamon, New York (1960)

6) Page, I.H. and Bumpus, F.M.: Physiol. Rev. 41, 331 (1961)

7) Hodgl, R.L., NG, K.K.F. And Vane, J.R.: Nature 215, 138 (1967)

8) Watanabe, T.X., Sokabe, H., Nakayama, T., Nakajima, T., Honda, 1. and Sakibara, S.: Folia pharmacol. japon. 72, 83P (1976) (in Japanese)

9) WatANABE, T.X. AND SOKABE, H.: Folia pharmacol. japon. (in Japanese) (in press) 